\title{
MANAJEMEN PENDIDIKAN ISLAM PERIODE MADINAH PERSPEKTIF AL MUBARAKFURI
}

\author{
Iqbal Asid Maududin', Abas Mansur Tamam², Wido Supraha ${ }^{3}$ \\ ${ }^{1,2,3}$ Universitas Ibn Khaldun Bogor \\ email: achid.musyaf@gmail.com
}

\begin{abstract}
Problems with educational institutions such as institutional relationships that are not harmonious with the surrounding community, unstable economic institutions, and others are often encountered at this time due to the lack of good management of Islamic educational institutions. Management science that can be explored and analyzed is the thought of al-Mubarakfuri in his work of al-Rahiq al-Makhtum. So the purpose of writing this study is to analyze the management of Islamic education from the perspective of alMubarakfuri in the book al-Rahiqu al-Makhtum. The method used is a qualitative research method literature study. Namely the author analyzes the book al-Rahiq alMakhtum in terms of educational management. The researcher analysis will focus on the Medina period. After analyzing and classifying the concept of management of Islamic education in the Medina period, the researcher then collected theories and other information from various sources related to the research theme. The results of the research found that there were six concepts of educational management in the Medina period, namely: a) determining the location as an education center, $b$ ) building a mosque, c) building Islamic brotherhood (Ukhuwah Islamiyah), d) building harmony with local residents, e) deliberation, and f) build and strengthen the economy of the people. So the conclusion of this study is the discovery of six concepts of management of Islamic education in the Medina period of the perspective of al-Mubarakfuri in al-Rahiq alMakhtum. These six management concepts can be a guide and are important things that must be considered by schools or Islamic educational institutions.
\end{abstract}

Keyword: management of islamic education, medina period, al-mubarakfuri.

\begin{abstract}
ABSTRAK
Permasalahan lembaga pendidikan seperti hubungan lembaga yang tidak rukun dengan masyarakat sekitar, ekonomi lembaga yang kurang stabil, dan lainnya kerap dijumpai pada saat ini karena kurang baiknya manajemen lembaga pendidikan Islam. Ilmu manajemen yang dapat digali dan ditelaah adalah pemikiran al-Mubarakfuri dalam karya beliau al-Rahiq al-Makhtum. Maka tujuan penulisan penelitian ini adalah untuk menganalisis manajemen pendidikan Islam perpektif al-Mubarakfuri dalam kitab alRahiqu al-Makhtum. Metode yang dipakai adalah metode penelitian kualitatif studi pustaka. Yaitu penulis menganalisis kitab al-Rahiq al-Makhtum dari sisi manajemen pendidikannya. Analisis peneliti akan di fokuskan pada periode Madinah. Setelah menganalisis dan mengklasifikasi konsep manajemen pendidikan Islam pada periode Madinah, peneliti kemudian mengumpulkan teori dan informasi lainnya dari berbagai sumber yang berhubungan dengan tema penelitian. Hasil penelitian ditemukan ada enam konsep manajemen pendidikan pada periode Madinah, yaitu: a) menentukan lokasi sebagai pusat pendidikan, b) membangun masjid, c) membangun persaudaraan Islam (Ukhuwah Islamiyah), d) membangun kerukunan dengan warga sekitar, e) musyawarah, dan f) membangun dan memperkuat ekonomi umat. Maka kesimpulan dari penelitian ini adalah ditemukannya Enam konsep manajemen pendidikan Islam periode madinah perspektif al-Mubarakfuri dalam al-Rahiq al-Makhtum. Keenam konsep manajemen ini dapat menjadi panduan dan menjadi hal penting yang harus diperhatikan oleh sekolah atau lembaga pendidikan Islam.
\end{abstract}

Kata kunci: manajemen pendidikan Islam, periode madinah, al-mubarakfuri. 


\section{PENDAHULUAN}

Pendidikan merupakan kebutuhan sepanjang hayat. Dan setiap manusia membutuhkan pendidikan. Pendidikan adalah salah satu kebutuhan manusia yang sangat penting, karena manusia adalah makhluk yang Allah jadikan sebagai khalifah di atas muka bumi. Ia bertugas untuk memakmurkan dan mencegah kerusakan-kerusakan di bumi. Tugas tersebut tidak akan tercapai manakala manusia tidak mendapatkan pendidikan yang tepat dan benar. Salah satu bukti betapa pentingnya pendidikan, maka wahyu yang pertama kali turun ialah perintah untuk membaca (QS Al 'Alaq:1) karena dengan membaca- yang merupakan salah satu metode pendidikan- akan mampu menghantarkan manusia menjadi makhluk yang berpendidikan sehingga mampu mewujudkan tugasnya sebagai seorang khalifatullah di atas muka bumi.

Untuk mempermudah mencapai tujuan pendidikan yang efisien dan efektif, maka manajemen pendidikan adalah hal yang pasti diperlukan. Karena dengan manajemen pendidikan kegiatan pendidikan dan prosesnya dapat terencana, terorganisir, terarahkan sekaligus juga dapat terawasi dan terevaluasi.

Akhir-akhir ini, manajemen sebagai ilmu begitu popular sehingga banyak kajian yang difokuskan pada manjemen baik berupa pelatihan, seminar, kuliah, maupun pembukaan program studi manajemen meliputi manajemen ekonomi, manajemen sumber daya manusia, manajemen pendidikan, dan sebagainya. Dalam perkembangan selanjutnya, manajemen telah diimplementasikan dalam berbagai persoalan yang bersifat batiniyah, seperti manajemen qalbu. Awal mulanya, tema manajemen hanya popular dalam dunia perusahaan atau bisnis. Kemudian tema ini digunakan dalam profesi lainnya, termasuk oleh pendidikan dengan beberapa modifikasi dan spesifikasi tertentu lantaran terdapat perbedaan objek. Dalam pandangan ajaran Islam, segala sesuatu harus dilakukan secara rapi, benar, tertib, dan teratur, proses-prosesnya harus diikuti dengan baik. Sesuatu tidak boleh dilakukan secara asal-asalan (Didin dan Hendri, 2013:1).

Mulai urusan terkecil seperti mengatur urusan rumah tangga sampai dengan urusan terbesar seperti mengatur urusan sebuah negara semua itu diperlukan pengaturan yang baik, tepat dan terarah dalam bingkai sebuah manajemen agar tujuan yang hendak dicapai bisa diraih dan bisa selesai secara efisien dan efektif. Maka manajemen dalam arti mengatur segala sesuatu agar dilakukan dengan baik, tepat dan terarah agar tujuan dapat 
dicapai dengan baik dan tuntas adalah hal yang disyariatkan dalam agama Islam (Didin dan Hendri, 2013:1). Nabi Muhammad bersabda yang artinya:

“Sesungguhnya Allah sangat mencintai orang yang apabila mengerjakan suatu pekerjaan, dikerjakan secara itqon (tepat, terarah, jelas dan tuntas)". (HR. Thabrani dalam al-Mu'jam al-Awsat, No. 897)

Juga sabda beliau yang lain yang diriwayatkan oleh imam Muslim, yang artinya:

“Sesungguhnya Allah 留 mewajibkan untuk berbuat ihsan dalam segala sesuatu..."

Kata ihsan dalam bahasa arab adalah bermakna baik. Maka termasuk hal baik yang wajib kita lakukan dalam dunia pendidikan adalah dengan cara memanajemennya secara baik. Agar proses pendidikan dapat berjalan dengan maksimal dan optimal.

Dalam praktiknya, yang mengatur dan mengelola manajemen pendidikan adalah yayasan pendidikan tersebut. Karena secara struktur organisasi pendidikan, yayasan berada diatas unit-unit pendidikan. Tugasnyalah yang mengatur, merencanakan, membuat kebijakan, mengarahkan, mengawasi serta mengevaluasi agar program pendidikan berjalan sesuai dengan visi dan misi yang sudah direncanakan sejak awal.

Maka dapat dikatakan, bahwa bagus dan tidaknya kualitas suatu unit pendidikan sangat bergantung pada kualitas yayasan yang mengelolanya. Apabila yayasan tersebut memiliki sistem manajemen yang unggul, maka unit-unit sekolah yang dibawahinya juga akan bagus dan maju. Namun, apabila yayasan tidak memiliki sistem manajemen yang unggul, maka akan mundur dan terbelakang unit-unit sekolah yang dibawahinya.

Semakin pesatnya pertumbuhan yayasan-yayasan pendidikan Islam tentu menjadi hal yang sangat menggembirakan bagi kita semua. Karena hal itu akan menambah terbuka lebarnya kesempatan untuk membentuk generasi islami dan rabbani pada anak-anak kaum muslimin. Hal ini tentunya harus dibarengi pula dengan penguatan dan perbaikan manajemen yayasan-yayasan tersebut. Agar arah dan tujuan pendidikan Islam senantiasa terjaga dan dapat tercapai secara maksimal dan optimal.

Salah satu unsur manajemen yang harus diperhatikan adalah bagaimana yayasan pendidikan Islam memanajemen lingkungan dan masyarakatnya. Karena lingkungan dan masyarakat sangat berpengaruh pada proses keberhasilan pendidikan. Kita dapat melihat fakta dilapangan beberapa yayasan atau unit pendidikan Islam yang diusir oleh masyarakat sekitarnya. Sebagai contoh, diberitakan oleh Metro, pada tahun 2011 sekolah Al Islah yang terletak di Jakata Pusat diminta untuk angkat kaki dari gedung yang ditempatinya. Lantaran ada permasalahan izin pemakaian gedung yang mereka gunakan. 
Yang terbaru, sebagaimana dikutip dari Ayo Bogor, pada tahun 2017 Yayasan Pendidikan Islam Ahmad bin Hanbal yang terletak di kota Bogor bersengketa dengan masyarakat sekitar. Para masyarakat sampai berdemo didepan balai kota Bogor menuntut agar izin mendirikan bangunan masjid yayasan tersebut dicabut.

Dari dua contoh kasus diatas menunjukkan betapa pentingnya manajemen kemasyarakatan pendidikan. Oleh karena itu yayasan pendidikan Islam harus senantiasa menggali sumber-sumber ilmu manajemen. Tidak berpuas dengan manajemen yang telah ia miliki saat ini. Karena ilmu manajemen pendidikan senantiasa berkembang sesuai dengan perkembangan zaman.

Selain lingkungan dan masyarakat sekitar yang harus diperhatikan dalam manajemen yayasan pendidikan Islam, beberapa hal lain yang perlu diperhatikan juga adalah masalah lokasi yayasan, sarana dan fasilitas pendidikan, sumber pemasukan dana atau ekonomi yayasan, membangun keharmonisan antar pegawai dan lain sebagainya.

Hal-hal di atas apabila tidak dimanajemen dengan baik maka akan berdampak negatif pada keberlangsungan yayasan pendidikan. Beberapa kasus dalam dunia pendidikan berikut dapat menjadi contoh dan pelajaran untuk yayasan pendidikan Islam yang tidak mempunyai sistem manajemen yang baik.

Kasus pertama, salah satu SDN di daerah Yogyakarta terancam ditutup lantaran tidak mempunyai cukup peserta didik. Diberitakan sebagaimana dilansir oleh salah satu media koran online, Kompas, pada tahun ajaran 2019-2020 SDN Wonolagi di Gunung Kidul, Yogyakarta, tidak ada pendaftar baru untuk kelas I (satu). Bahkan diberitakan juga bahwa jumlah peserta didik sekolah ini hanya 11 orang saja. Kelas II sebanyak 4 (empat) orang, kelas III sebanyak 4 (tiga) orang, dan kelas IV sebanyak 4 (empat) orang. Faktor semakin berkurangnya jumlah peserta didik lantaran karena terpencilnya lokasi sekolah, juga karena di daerah tersebut memang tidak ada anak yang berumur tujuh tahun atau lulusan TK. Ini salah satu kasus yang menunjukkan betapa pentingnya manajamen pemilihan lokasi sebagai pusat pendidikan.

Kasus kedua, mengutip dari Kompas, kebakaran yang melanda lembaga pendidikan Yayasan Harapan Salahudin di jalan Muara Baru, Jakarta Utara, masih belum selesai diperbaiki. Padahal, kebakaran yang melanda sekolah itu sudah 10 bulan lewat sejak awal kebakaran di bulan September 2016. Dari delapan ruangan yang terbakar, ada dua ruangan yang sama sekali belum tersentuh perbaikan. Pihak Tata Usaha sekolah, Ahmad, mengatakan seluruh biaya perbaikan sekolah ditanggung oleh yayasan. Saat ini pihak yayasan telah mengajukan permohonan dana bantuan ke Dinas Pendidikan DKI Jakarta. 
Namun hingga saat ini (Juli 2017) bantuan tak kunjung didapatkan. Bagi Peneliti, antara ekonomi dan pendidikan adalah dua hal yang sangat berkaitan erat yang tidak dapat dipisahkan satu sama lain. Yayasan yang ditopang oleh ekonomi yang mapan akan lebih mudah menjalankan operasional dan program-programnya ketimbang yayasan yang masih lemah ekonominya.

Di antara masalah pendidikan yang timbul akibat faktor ekonomi menurut Peneliti juga adalah semakin naiknya biaya pendidikan saat ini. Bagi yayasan yang pemasukan dananya hanya mengandalkan dari SPP bulanan para peserta didik, akan mudah menaikkan biaya SPP jika ada kekurangan dalam biaya operasionalnya. Hal ini akan berbeda jika yayasan pendidikan mempunyai unit-unit usaha yang membantu menopang pembiayaan operasional pendidikan.

Kasus ketiga, hubungan internal pada lembaga pendidikan yang kurang harmonis akan berimbas pada proses belajar dan mengajar. Hal ini juga dialami oleh SD Islam Al Azhar 24. Dikutip dari Detik, Para pengurus yayasan lama menyegel sekolah tersebut dengan menempel lembar kertas yang berisi teguran kepada Yayasan Pesantren Islam Al Azhar sebagai pengurus baru agar dapat memperpanjang kerjasama yang telah disepakati keduanya. Akibat penyegelan sekolah tersebut, para peserta didik harus rela belajar di luar kelas. Maka bagi peneliti, membangun keharmonisan sesama pengurus internal juga sangat penting diperhatikan dalam manajemen yayasan pendidikan Islam.

Masalah-masalah di atas hanyalah sebagian kecil permasalahan yang terjadi dalam dunia pendidikan. Tentunya di sana masih banyak kasus-kasus lain yang terjadi akibat dari kurang baiknya dalam memanajemen yayasan pendidikan Islam.

Salah satu sumber ilmu manajemen yang dapat digali dan ditelaah adalah pemikiran al-Mubarakfuri dalam karya beliau al-Rahiq al-Makhtum. Buku ini adalah biografi (sirah) Nabi Muhammad semenjak sebelum beliau dilahirkan hingga beliau wafat. Bila dicermati, dalam sirah nabawiyah mengandung pelajaran-pelajaran yang sangat penting serta ilmu manajemen bagaimana Rasulullah merencanakan, mengatur, dan mengelola pendidikan Islam secara maksimal dan optimal. Manajemen pendidikan Islam yang dikelola oleh Rasulullah para generasi terbaik yang mampu membawa perubahan peradaban manusia ke arah yang yang lebih baik di seluruh dunia.

Adapun alasan peneliti memilih buku al Rahiqu al Makhtum adalah karena buku ini telah dinyatakan sebagai penulisan buku sirah nabi terbaik (juara pertama) dalam kompetisi (musabaqah) yang diadakan oleh Muslim World League atau Rabitah Alam Al 
Islami. Buku ini sudah banyak dialih bahasakan ke berbagai bahasa di seluruh dunia, termasuk bahasa Indonesia. Di samping itu, cara penyajian yang tidak berbelit-belit serta fokus terhadap materi sirah membuat buku ini nyaman serta tidak membosankan untuk terus dibaca.

Alasan berikutnya karena dalam buku ini lebih banyak ditekankan bagaimana cara memanajemen pendidikan secara komplek. Berbagai sisi pendidikan sangat diperhatikan dan dikelola dengan baik. Seperti memilih lokasi pendidikan, membina hubungan yang harmonis dengan masyarakat sekitar, membangun kekuatan ekonomi, dan lain sebagainya. Begitu banyak hal yang bisa dianalisis dan dipelajari dari buku tersebut dalam hal manajemen pendidikan, yang bisa jadi sisi-sisi tersebut belum terpikirkan oleh kita.

Dalam mengkaji buku sirah karya Shafiyyur Rahman al-Mubarakfuri ini peneliti akan memfokuskan pada hal-hal yang berkaitan dengan bagaimana manajemen pendidikan agama Islam di masa Nabi Muhammad. Kemudian pembahasan akan lebih difokuskan lagi pada manajemen pendidikan Islam di periode Madinah. Yaitu periode semenjak Rasulullah hijrah ke Madinah hingga beliau wafat.

Adapun alasan peneliti memilih periode Madinah sebagai objek penelitian adalah karena pada periode ini manajemen pendidikannya lebih komplek dan menyeluruh dibanding pada manajemen pendidikan periode Mekah. Banyak hal baru yang Rasulullah 政-lakukan pada periode ini yang tidak beliau lakukan pada periode pendidikan Mekah. Sehingga semakin banyak pelajaran yang dapat diambil, terutama dalam sisi menajemen pendidikannya. Harapan peneliti pada hasil penelitian ini agar dapat memberikan sumbangsih konsep manajemen pendidikan Islam yang benar dan tepat agar proses pendidikan berjalan dengan lancar dengan hasil pendidikan yang maksimal dan optimal.

\section{TINJAUAN PUSTAKA}

\section{Pengertian Manajemen}

Secara etimologis, kata manajemen berasal dari Bahasa Inggris, yakni management, yang dikembangkan dari kata to manage, yang artinya mengatur atau mengelola. Kata manage itu sendiri berasal dari Bahasa Italia, maneggio, yang diadopsi dari Bahasa Latin managiare, yang berasal dari kata manus, yang artinya tangan (Sadili, 2006:17).

Dalam Kamus Besar Bahasa Indonesia Manajemen memiliki arti: “penggunaan sumber daya secara efektif untuk mencapai sasaran, dan pimpinan yang bertanggung jawab atas jalannya perusahaan dan organisasi”. 
Sedangkan secara terminologi terdapat banyak definisi yang dikemukakan oleh para ahli. Menurut George R. Terry dikutip dari Sadili Samsudin, 'Management is a distinct process consisting of planning, organizing, actuating, and controlling performance to determine and accomplish stated objectives by the use of human being and other resources. (Manajemen merupakan sebuah proses yang khas, yang terdiri dari tindakantindakan: perencanaan, pengorganisasian, pengarahan dan pengawasan, yang dilakukan untuk menentukan serta mencapai sasaran-sasaran yang telah ditetapkan melalui pemanfaatan sumber daya manusia dan sumber-sumber daya lainnya'(Sadili, 2006:17).

Harold Konts dan Cyril O'Donell, dikutip dari Hasibuan, dalam bukunya "Manajemen Dasar, Pengertian dan Masalah". 'Management is getting things done through people. (Manajemen adalah penyelesaian pekerjaan melalui orang lain'(Hasibuan, 1996:3).

Kemudian definisi Manajemen menurut Massie dikutip dari Azhar Arsyad menyatakan 'Manajemen adalah suatu proses dimana kelompok secara kerjasama mengerahkan tindakan atau kerjanya untuk mencapai tujuan bersama. Proses tersebut mencakup teknik-teknik yang digunakan oleh para manajer untuk mengkoordinasikan kegiatan atau aktifitas orang lain menuju tercapainya tujuan bersama'(Azhar, 1996:1).

Sedangkan menurut Handoko, manajemen adalah "proses perencanaan, pengorganisasian, pengarahan, dan pengawasan dengan memberdayakan anggota organisasi dan penggunaan sumber daya organisasi lainnya agar mencapai tujuan organisasi yang telah ditetapkan" (Handoko, 2003:8).

Dari berbagai definisi manajemen diatas, dapat peneliti simpulkan, bahwa manajemen adalah proses perencanaan, pengorganisasian, pelaksanaan, pengawasan, dan evaluasi yang dilakukan terus menerus untuk mencapai tujuan, baik itu secara pribadi maupun secara jamaah (organisasi).

\section{Fungsi-Fungsi Manajemen}

Definisi manajemen memberikan tekanan terhadap kenyataan bahwa segala sesuatu yang dimanajemen dengan baik maka akan menghasilkan hasil yang maksimal dan optimal.

Daft menyebutkan dikutip dari Abdul Choliq, 'manajemen mempunyai empat fungsi, yakni perencanaan (planning), pengorganisasian (organizing), kepemimpinan (leading), dan pengendalian (controlling). Dari fungsi dasar manajemen tersebut, kemudian dilakukan tindak lanjut setelah diketahui bahwa yang telah ditetapkan tercapai atau belum Tercapai'(Choliq, 2011:36). 
Ahli manajemen G.R. Terry menyebutkan dalam kutipan Hasibuan, fungsi-fungsi manajemen adalah Planning, Organizing, Actuating, Controlling. Sedangkan menurut John F. Mee fungsi manajemen diantaranya adalah Planning, Organizing, Motivating dan Controlling. Berbeda lagi dengan pendapat Henry Fayol ada lima fungsi manajemen, diantaranya Planning, Organizing, Commanding, Coordinating, Controlling, dan masih banyak lagi pendapat pakar-pakar manajemen yang lain tentang fungsi-fungsi manajemen. Dari fungsi-fungsi manajemen tersebut pada dasarnya memiliki kesamaan yang harus dilaksanakan oleh setiap manajer secara berurutan supaya proses manajemen itu diterapkan secara baik (Hasibuan, 2005:3-4).

Meskipun para ahli tidak satu kata dalam menyebutkan fungsi manajemen, namun pendapat mereka menurut peneliti justru saling melengkapi satu sama lain, dan tidak berbenturan sama sekali. Adapun beberapa fungsi manajemen yang mereka sepakati selanjutnya akan dibahas satu persatu agar lebih jelas.

\section{Perencanaan}

Perencanaan adalah suatu rangkaian persiapan tindakan untuk mencapai tujuan. Perencanaan merupakan pedoman, garis besar, atau petunjuk yang harus dituruti jika menginginkan hasil yang baik. Dalam menyusun sebuah rencana, hal pertama yang harus dilakukan adalah, anda harus memusatkan pikiran kepada apa yang ingin dikerjakan, tujuan jangka pendek dan tujuan jangka panjang untuk organisasi serta memutuskan alat apa yang akan digunakan untuk mencapai tujuan tersebut. Anda harus meramalkan sejauh mana kemungkinan tersebut dapat dicapai, baik dilihat dari aspek ekonomi, sosial, maupun lingkungan politik tempat organisasi berorganisasi serta dihubungkan dengan sumber-sumber yang ada untuk mewujudkan rencana tersebut (Taufiqurokhman, 2008:3).

Sementara Widjojo dalam Lembaga Administrasi Negara (1985:31) dikutip dari Taufiqurokhman menjelaskan, 'perencanaan pada asasnya berkisar pada dua hal : 1. Penentuan pilihan secara sadar mengenai tujuan-tujuan konkret yang hendak dicapai dalam jangka waktu tertentu atas dasar nilai-nilai yang dimiliki masyarakat yang bersangkutan. 2. Pilihan di antara cara-cara alternatif yang efesien serta rasional guna mencapai tujuan-tujuan tersebut, baik untuk penentuan tujuan yang meliputi jangka waktu tertentu maupun bagi pemilihan cara-cara tersebut diperlukan ukuran-ukuran atau kriteria-kriteria tertentu yang terlebih dahulu harus dipilih pula' (Taufiqurokhman, 2008:3). 
Lebih lanjut Taufiqurokhman menjelaskan bahwa "perencanaan adalah suatu proses menentukan apa yang ingin dicapai pada masa yang akan datang serta menetapkan tahapan-tahapan yang dibutuhkan untuk mencapainya". (Taufiqurokhman, 2008:3)

Menurut Handoko, sebelum manajer dapat mengorganisasikan, mengarahkan atau mengawasi, mereka harus membuat rencana-rencana yang memberikan tujuan dan arah organisasi. Dalam perencanaan, manajer memutuskan "apa yang harus dilakukan, kapan melakukannya, bagaimana melakukannya, dan siapa yang melakukannya". Jadi, perencanaan adalah pemilihan sekumpulan kegiatan dan pemutusan selanjutnya apa yang harus dilakukan, kapan, bagaimana dan oleh siapa (Handoko, 1999:79).

2. Pengorganisasian

Setelah yayasan telah menetapkan tujuan-tujuan dan menyusun rencana-rencana atau program-program, maka untuk mencapainya mereka perlu merancang dan mengembangkan suatu organisasi yang akan melaksanakan berbagai program tersebut secara maksimal.

Adapun maksud dari pengorganisasian itu sendiri, Handoko menyebutkan bahwa organizing adalah 1) penentuan sumber daya-sumber daya dan kegiatan-kegiatan yang dibutuhkan untuk mencapai tujuan organisasi, 2) perancangan dan pengembangan suatu organisasi kelompok kerja yang akan dapat membawa hal-hal tersebut kearah tujuan., 3) penugasan tanggung jawab tertentu dan kemudian, 4) pendelegasian wewenang yang diperlukan kepada individu-individu untuk melaksanakan tugas-tugasnya. Fungsi ini menciptakan struktur formal dimana pekerjaan ditetapkan, dibagi dan dikoordinasikan (Handoko, 1999:24).

Sedangkan menurut Nanang Fattah, pengorganisasian adalah proses membagi kerja ke dalam tugas-tugas yang lebih kecil, membebankan tugas-tugas itu kepada orang yang sesuai dengan kemampuannya, dan mengalokasikan sumber daya, serta mengkoordinasikannya dalam rangka efektivitas pencapaian tujuan organisasi (Nanang, 2004:71). Lain halnya dengan Stoner dalam Tim Dosen menyatakan, bahwa mengorganisasikan adalah proses mempekerjakan dua orang atau lebih untuk bekerja sama dalam cara terstruktur guna mencapai sasaran spesifik atau beberapa sasaran. (Tim Dosen Administrasi Pendidikan Universitas Pendidikan Indonesia, 2011:94). 
Jadi pengorganisasian merupakan tahapan lanjutan setelah perencanaan untuk mencapai tujuan. Menurut peneliti, berorganisasi dalam Islam dapat juga disebut dengan berjamaah. Allah berfirman dalam surat al-Maidah ayat 2:

Dan tolong-menolonglah kamu dalam (mengerjakan) kebajikan dan takwa, dan jangan tolong-menolong dalam berbuat dosa dan pelanggaran. Dan bertakwalah

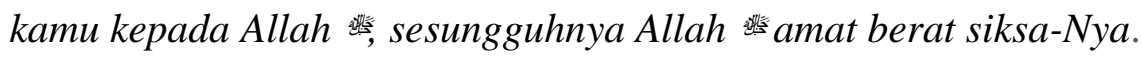

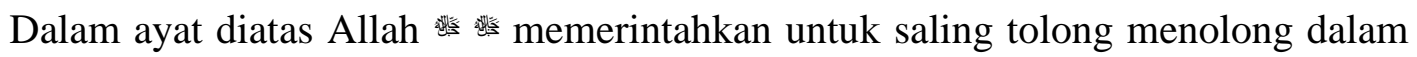
hal kebaikan dan ketakwaan. Maka pengorganisasian dalam rangka saling membantu tugas satu sama lain untuk mencapai tujuan yang baik itu juga masuk ke dalam anjuran ayat tersebut di atas. Nabi Muhammad juga memberikan kabar

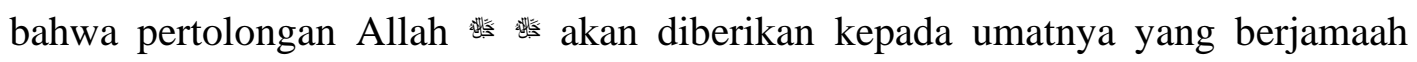
dalam hal kebaikan. Beliau bersabda yang diriwayatkan oleh Ibnu Abbas: “ Tangan (pertolongan) Allah 些 bersama orang yang berjamaah”. (HR. AtTirmidzi, no 2167).

\section{Penggerakkan}

Setelah perencanaan dan pengorganisasian, maka tahap selanjutnya adalah mewujudkan tujuan dengan cara menggerakkan organisasai yang sudah terbentuk. Tahap ini disebut dengan actuating yang artinya penggerakkan/pelaksanaan.

Ernie menyatakan, "Pelaksanaan, pengimplementasian, atau penggerakkan (actuating) merupakan proses implementasi program agar bisa dijalankan oleh seluruh pihak dalam organisasi serta proses memotivasi agar semua pihak dapat bertanggungjawab dengan penuh kesadaran dan produktivitas yang tinggi" (Ernie, 2010:8).

Haris menyebutkan dalam Nurul Riza Arumsari prinsip yang harus dipegang dalam fungsi actuating atau penggerakan diantaranya: 'a. Prinsip yang tertuju pada sasaran dimana dalam melaksanakan fungsi actuating penting mendapatkan dukungan dari fungsi-fungsi yang lain seperti planning, organizing, staffing dan controlling yang efektif b. Prinsip keselarasan dengan sasaran dimana seorang bekerja untuk mencukupi kebutuhannya. Kebutuhan akan terpenuhi apabila karyawan dapat bekerja dengan efektif dan menyumbangkan keahliannya untuk mencapai sasaran dari organisasi. c. Prinsip kesatuan komando dimana seorang bawahan hanya mempuyai satu alur dalam melaporkan kegiatannya. Pelaporan 
tersebut ditujukan hanya kepada satu atasan sehingga konflik dalam pemberian arahan dapat dikurangi' (Nurul, 2017).

Dapat dikatakan bahwa tahap pengerakkan organisasi merupakan motor yang mampu menghidupkan program-program untuk menuju tujuan awal diperencanaan.

4. Pengawasan

Tahap terakhir dari fungsi manajemen adalah memastikan semua program berjalan dengan baik dan optimal. Tahap ini disebut dengan tahap Pengawasan (controlling).

Adapun definisi pengawasan menurut Yahya adalah proses untuk menjamin bahwa tujuan-tujuan organisasi dan manajemen dapat tercapai. Ini berkenaan dengan caracara membuat kegiatankegiatan sesuai yang direncanakan. Pengertian ini menunjukkan adanya hubungan yang sangat erat antara perencanaan dan pengawasan (Yahya, 2006:133).

Robert J. Mockler berpendapat dikutip dari Zamani, 'bahwa pengawasan manajemen adalah suatu usaha sitematik untuk menetapkan standart pelaksanaan dengan tujuan-tujuan perencanaan, merancang sistem informasi, umpan balik, membandingkan kegiatan nyata dengan standard yang telah ditetapkan sebelumnya, menentukan dan mengukur penyimpangan-penyimpangan serta mengambil tindakan koreksi yang diperlukan untuk menjamin bahwa semua sumber daya perusahaan dipergunakan dengan cara efektif dan efisien dalam pencapaian tujuan-tujuan perusahaan' (Zamani, 1998:132).

Kadarisman menjelaskan bahwa "Kontrol atau pengawasan adalah fungsi di dalam manajemen fungsional yang harus dilaksanakan oleh setiap pimpinan semua unit/satuan kerja terhadap pelaksanaan pekerjaan atau pegawai yang melaksanakan sesuai dengan tugas pokoknya masing-masing. Dengan demikian, pengawasan oleh pimpinan khusunya yang berupa pengawasan melekat (built in control), merupakan kegiatan manajerial yang dilakukan dengan maksud agar tidak terjadi penyimpangan dalam melaksanakan pekerjaan. Suatu penyimpangan atau kesalahan terjadi atau tidak selama dalam pelaksanaan pekerjaan tergantung pada tingkat kemampuan dan keterampilan pegawai. Para pegawai yang selalu mendapat pengarahan atau bimbingan dari atasan, cenderung melakukan kesalahan atau penyimpangan yang lebih sedikit dibandingkan dengan pegawai yang tidak memperoleh bimbingan" (Kadarisman, 2013:172). 
Dari uraian pendapat para ahli di atas, dapat peneliti simpulkan bahwa pengawasan adalah tahap untuk memastikan agar setiap apa yang dikerjakan senantiasa berada dalam jalur yang tepat untuk mencapai tujuan, bila ada penyimpangan maka ada tindakan koreksi.

Adapun fungsi pengawasan menurut Arifin Abdul Rachman adalah: a) Untuk mengetahui apakah segala sesuatu berjalan sesuai dengan rencana yang telah ditetapkan b) Untuk mengetahui apakah segala sesuatu telah berjalan sesuai dengan instruksi serta prinsip-prinsip yang telah ditetapkan c) Untuk mengetahui apakah kelemahan-kelemahan serta kesulitankesulitan dan kegagalan-kegagalan, sehingga dapat diadakan perubahanperubahan untuk memperbaiki serta mencegah pengulangan kegiatan yang salah. d) Untuk mengetahui apakah segala sesuatu berjalan efisien dan apakah tidak dapat diadakan perbaikan-perbaikan lebih lanjut, sehingga mendapat efisiensi yang lebih besar (Arifin, 2001:23).

\section{METODE PENELITIAN}

\section{Jenis Penelitian}

Dalam penelitian ini menggunakan metodelogi penelitian kualitatif dengan pendekatan library research (studi pustaka). Untuk metodelogi penelitian studi pustaka, maka penggalian sumber-sumber informasi didapat melalui telaah dan analisis buku-buku yang berkaitan dengan manajemen yang terdapat pada buku-buku sirah nabawiyah. Dari literatur tersebut dapat ditemukan berbagai pendapat yang digunakan untuk menganalisis dan menjawab permasalahan penelitian.

Berdasarkan jenis data, penelitian ini adalah penelitian kualitatif. Karakteristik penelitian kualitatif antara lain; Pertama, lebih bersifat deskriftif. Kedua, data yang terkumpul berbentuk kata-kata atau gambar, sehingga tidak menekankan pada angka. Ketiga, penelitian kualitatif lebih menekankan pada proses daripada produk atau outcome. Keempat, lebih menekankan makna (data dibalik yang teramati) (Sugiyono, 2008: 65-70).

Dengan demikian, penelitian ini memberikan sebuah deskripsi tentang manajemen pendidikan Islam sehingga dapat memberikan pengaruh dalam pengelolaan manajemen Lembaga atau Yayasan pendidikan Islam.

\section{Pendekatan Penelitian}

Penelitian kualitatif dapat dibedakan menjadi dua macam, yaitu: Pertama, Penelitian kualitatif dalam paradigma kuantitatif (positivisme). Penelitian kualitatif jenis pertama ini menggunakan paradigma positivisme. Kriteria kebenaran menggunakan ukuran frekwensi 
tinggi. Data yang terkumpul bersifat kuantitatif kemudian dibuat kategorisasi baik dalam bentuk tabel, diagram maupun grafik. Hasil kategorisasi tersebut kemudian dideskripsikan, ditafsirkan dari berbagai aspek, baik dari segi latar belakang, karakteristik dan sebagainya. Dengan kata lain data yang bersifat kuantitatif ditafsirkan dan dimaknai lebih lanjut secara kualitatif. Beberapa peneliti menyebut dengan istilah penelitian deskriptif kualitatif.

Kedua, Penelitian kualitatif dalam paradigma bahasa. Penelitian kualitatif dalam paradigma bahasa (dan sastra) menggunakan paradigma post positisme. Penelitian kualitatif jenis kedua ini berusaha mencari makna, baik makna di balik kata, kalimat maupun karya sastra.

Dalam penelitian ini menggunakan pendekatan rasionalistik. Pendekatan rasionalistik menurut Noeng Muhajir (1992:83), adalah "pendekatan yang menekankan pemaknaan empirik, pemahaman intelektual dan kemampuan berargumentasi secara logik”.

\section{Sumber Data}

Peneliti membagi Sumber data menjadi dua, yaitu: sumber data primer (utama), dan sumber data sekunder (penunjang). Adapun data primer yaitu dari kitab al-Rahiq alMakhtum karya al-Mubarakfuri. Kemudian data sekunder jurnal-jurnal ilmiyah dan karyakarya yang masih relavan dengan judul penelitian.

\section{Teknik Pengolahan dan Analisis Data}

Data yang terkumpul melalui proses elaborasi dari berbagai sumber, diklasifikasi, diseleksi dan disusun sesuai kategori data yang diperlukan untuk pembahasan rumusan masalah yang ditemukan kemudian dianalisis. Berdasarkan data yang ada, maka analisis data yang digunakan adalah analisis kualitatif deskriptif. Data kualitatif dianalisa dengan jalan mengklasifikasi dan mengkategorisasikannya. dengan kata lain, data dianalisa dengan mengatur urutannya, mengorganisasikan ke dalam suatu pola, kategori, dan satuan uraian dasar (Burhan, 2006:83-84).

Data yang telah diperoleh dari suatu sumber diolah dan dianalisis dengan menggunakan analisis isi (content analysis). Penarikan kesimpulan dilakukan dengan kesimpulan yang bersifat induktif, deduktif, atau komparatif. Kesimpulan induktif dimulai dari data yang bersifat khusus, kemudian dibuat kesimpulan yang bersifat umum. Kesimpulan deduktif dilakukan dengan menganalisis data yang bersifat umum dan diperkuat dengan data yang bersifat khusus. Sedangkan kesimpulan komparatif dilakukan dengan membandingkan beberapa pendapat, data, dan teori, sehingga dari keseluruhan permasalahan dapat dijawab. Pada bagian ini akan muncul kesimpulan kesimpulan yang mendalam secara komprehensif dari data hasil penelitian. 


\section{PEMBAHASAN}

\section{Manajemen Pendidikan Islam Pada Periode Madinah Perspektif al-Mubarakfuri}

Periode Madinah adalah periode yang dimulai dari hijrahnya Nabi Muhammad dari Mekah ke Madinah, dan berakhir hingga beliau wafat. Menurut al-Mubarakfuri, periode Madinah dapat dibagi menjadi tiga tahapan:

Tahapan pertama, tahapan yang diliputi oleh suasana instabilitas dan penuh goncangan, terjadinya problem-problem internal serta merangsaknya para musuh ke Madinah untuk menghabisi para penduduknya dari luar. Tahapan ini berakhir hingga terjadinya Perjanjian Hudaibiyyah pada bulan Dzulqa'dah tahun enam Hijriah.

Tahapan kedua, tahapan genjatan senjata bersama para pimpinan kaum Paganis dan berakhir dengan terjadinya Penaklukan Mekkah (Fathu Makkah) pada bulan Ramadhan tahun delapan hijriah yang merupakan tahapan dakwah kepada para raja untuk menganut Islam.

Tahapan ketiga, tahapan berbondong-bondongnya manusia masuk Islam, yaitu tahapan berdatangannya para kabilah dan bangsa ke Madinah. Tahapan ini terus berlangsung hingga Rasulullah wafat pada bulan Rabi'ul Awwal tahun 11 Hijriah (alMubarakfuri, 2001:253).

Berdasarkan analisis Peneliti terhadap kitab al-Rahiq al-Makhtum, maka manajemen pendidikan Islam selama periode Madinah perspektif al-Mubarakfuri dapat dirumuskan dalam beberapa rumusan berikut:

1. Menentukan lokasi pendidikan

2. Membangun masjid

3. Membangun persaudaraan (ukhuwah) Islam

4. Membangun kerukunan dengan warga sekitar

5. Musyawarah

6. Membangun dan menguatkan ekonomi umat

Untuk lebih jelasnya akan dijabarkan secara rinci sebagaimana berikut.

\section{Memilih dan menentukan lokasi sebagai pusat pendidikan}

Memilih lokasi untuk dijadikan sebagai pusat pendidikan sangatlah penting sebelum dimulainya pendidikan itu sendiri. Hal itu karena lokasi pendidikan menjadi salah satu faktor yang berpengaruh pada pencapaian tujuan pendidikan. Oleh karena itu, Yayasan Pendidikan Islam yang akan membangun pusat pendidikan harus mencermati dan mempelajari lokasi sebelum menjadikannya sebagai tempat pusat pendidikan. 
Menurut al Mubarakfuri pemilihan lokasi yang tepat juga telah Rasulullah selama periode di Madinah. Diantaranya adalah sebagaimana berikut:

\section{Menentukan Madinah sebagai kota Hijrah}

Ketika Allah memerintahkan Rasulullah dan kaum muslimin untuk berhijrah ke Madinah, bukanlah hanya sekedar perintah untuk menyelamatkan diri dari segala penyiksaan dan ancaman kaum kafir Quraisy semata, akan tetapi lebih dari itu. Hijrah ke Madinah artinya merangkai kerjasama untuk membangun tatanan baru di negeri yang aman (al-Mubarakfuri, 2001:255).

Salah satu alasan Allah memilih kota Madinah sebagai kota hijrah untuk Rasulullah dan kaum muslimin adalah karena lokasinya yang strategis. Lokasi Madinah sebagai penghubung jalur perdagangan kedepannya sangat berpengaruh pada perekonomian penduduk Madinah. Dan juga sebagai daya tawar bagi kabilah-kabilah yang lain. Sa'ad bin Muadz -salah satu pemuka kaum Anshar- ketika sedang berthawaf di Ka'bah, Abu Jahal lantas mencoba untuk menghalang-halanginya. Saad membalasnya dengan mengatakan: "Demi Allah jika kau berani melarangku melakukan thawaf, niscaya aku akan melarangmu dengan hal yang lebih keras, yaitu mencegahmu melintasi jalur Madinah" (Al-Bukhori:563). Hal ini menunjukkan letak strategis kota Madinah sebagai jalur perdagangan yang menghubungkan kota mekkah dengan negeri Syam.

Selain karena letak Madinah yang strategis, kesanggupan dan kesiapan para penduduknya untuk menerima dan menolong dakwah agama Islam juga menjadi faktor utama alasan kenapa Madinah dijadikan sebagai kota hijrah. Sebelum Nabi berhijrah ke Madinah, beberapa penduduk Madinah datang ke mekkah dan melaksanakan bai'at kepada beliau yang dikenal dengan Bai'atul Aqabah (janji setia).

Menurut al Mubarakfuri pada bai'at Aqabah yang pertama dihadiri oleh 12 orang laki-laki. Imam Bukhori meriwayatkan sebagaimana yang dinukil oleh al-Mubarakfuri dari sahabat Ubadah bin Shamit ia berkata, Rasulullah bersabda;

“Berbaiatlah (berjanji) kalian semua kepadaku untuk: tidak menyekutukan Allah 此 dengan suatu apapun, tidak mencuri, tidak berzina, tidak membunuh anak-anakmu, tidak membuat fitnah di antara kalian, tidak durhaka terhadap perintah kebaikan. Barangsiapa yang menepati perjanjian itu maka ia akan diberi pahala oleh Allah dan barangsiapa yang melanggar salah satu dari perjanjian itu, maka ia akan dihukum di dunia ini. Hukuman itu menjadai kafarah (tebusan) baginya, dan barangsiapa yang melanggar salah satunya kemudian ditutup oleh Allah 紧, maka perkaranya terserah kepada Allah 些 Jika Dia berkehendak untuk mengampuninya, maka akan diampuni dan jika Dia 
berkehendak untuk menghukumnya, maka Dia akan menghukumnya." Maka kami pun berbaiat kepada Rasulullah atas yang demikian itu (al-Mubarakfuri, 2001:255).

Adapun pada saat baiat Aqabah yang kedua, Imam Ahmad meriwayatkan sebagaiman yang dinukil oleh al-Mubarakfuri dari Jabir ia berkata: “ ya Rasulullah untuk hal apa kami berbaiat kepadamu?" beliau bersabda:

“Untuk mendengar dan taat, baik dalam kondisi semangat atau malas, untuk berinfak dalam masa sulit atau mudah, untuk berbuat amar ma'ruf nahi munkar, untuk senantiasa tegak dijalan Allah tanpa memperdulikan celaan orang-orang, untuk memebelaku manakala aku datang kepada kalian, dan melindungiku sebagaimana kalian melindungi diri, istri-istri dan anak-anak kalian. Jika hal ini kalian lakukan, maka surgalah sebagai imbalan bagi kalian." (al-Mubarakfuri, 2001:213-214).

Dari poin-poin baiat Aqabah ini, secara jelas menunjukkan kesiapan dan loyalitas penduduk madinah untuk selalu mendukung dan menolong dakwah agama Islam disemua keadaan, baik disaat senang maupun sempit. Bahkan mereka telah berjanji setia untuk siap mengorbankan harta dan jiwa untuk melindungi Nabi sebagaimana mereka melindungi diri, harta, dan anak-istri mereka sendiri. Ini aspek yang sangat penting untuk menjadikan Madinah sebagai lokasi pusat pendidikan agama Islam.

\section{Memilih lokasi yang tepat untuk pasukan sebelum berperang}

Rasulullah senantiasa memilih lokasi yang strategis untuk base camp (perkemahan) pasukan kaum muslimin sebelum berperang. Seperti pada saat sebelum perang Badar, Rasulullah bergerak cepat bersama pasukan mendahului kaum Musyrikin untuk menguasai mata air Badar dan menghalangi mereka dari usaha menguasainya (alMubarakfuri, 2001:306).

Begitu pula ketika perang Khaibar, ketika Rasulullah telah memilih tempat perkemahan pasukan Islam, Hubab bin al Mundzir datang menemui beliau seraya bertanya, “Ya Rasulullah, lokasi yang engkau pilih ini apakah berdasarkan wahyu yang Allah 邆 turunkan kepadamu ataukah hanya siasat dalam perang?” Rasulullah menjawab, "ini hanyalah siasat perang." Hubab berkata, "Ya Rasulullah, lokasi ini terlalu dekat dengan benteng Nuthah, sedangkan seluruh pasukan Yahudi Khaibar ada di dalamnya. Mereka bisa mengetahui gerak-gerik kita tapi kita tidak bisa mengetahui gerak gerik mereka. Anak panah mereka bisa menjangkau kita tapi anak panah kita tidak bisa menjangkau mereka. Kita pun tidak aman dari sergapan mereka... andai saja engkau memerintahkan mencari tempat yang bebas dari bahaya untuk kita jadikan tempat perkemahan, maka itu akan lebih baik. Rasulullah bersabda, “ Siasat yang tepat adalah 
apa yang kamu paparkan."Kemudian dipindahkanlah perkemahan itu ke tempat yang lain (Al-Mubarakfuri, 2001:548).

Persetujuan Rasulullah atas analisis sahabat Hubab terhadap lokasi perkemahan menunjukkan pemilihan lokasi merupakan aspek yang sangat penting, baik dalam peperangan maupun dalam dunia pendidikan.

\section{Membangun Masjid}

Membangun masjid dalam sarana pendidikan Islam merupakan hal yang penting. Jumari mengatakan," manajemen sarana dan prasarana yang berkualitas merupakan faktor urgen/sangat penting dalam setiap upaya peningkatan kreativitas peserta didik”.

Oleh karena itu menurut al-Mubarakfuri, langkah pertama yang Rasulullah ambil setelah berhijrah ke Madinah adalah mendirikan masjid Nabawi. Beliau membangun masjid ini ditempat menderumnya unta beliau. Beliau membeli sebidang tanahnya dari dua orang anak yatim, sang pemiliknya. Beliau sendiri ikut terjun dalam pembangunan masjid, memindahkan batu bata dan batu lainnya untuk memotivasi para sahabat-sahabatnya (AlMubarakfuri, 2001:265).

Langkah pertama Rasulullah dengan membangun masjid tentu mengandung hikmah yang besar bila kita cermati, karena masjid adalah tempat sarana pendidikan para sahabat dan juga tempat penyucian jiwa (tazkiyatun nafs) mereka, dengan berbagai ibadah di dalamnya seperti shalat dan bermajelis dengan Rasul.

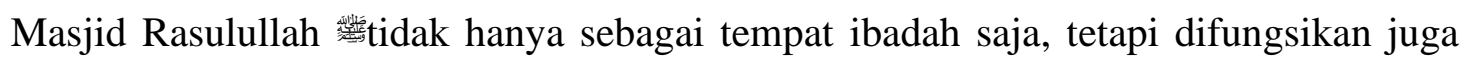
untuk hal-hal lain, baik yang berkaitan erat dengan pendidikan ataupun yang lainnya. Ali Musthafa Ya'kub menjelaskan dikutip dari Republika Khazanah, bahwa fungsi masjid di zaman Rasul ada lima, yaitu: shalat berjamaah, menuntut ilmu, musyawarah, merawat orang sakit, dan sebagai asrama. Namun menurut Ali Musthafa Ya'qub, Imam Besar Masjid Istiqlal, ada beberapa fungsi yang dirasa kurang tepat untuk diterapkan zaman sekarang. Dia menegaskan, fungsi Masjid sebagai asrama tidak tepat jika dilakukan saat ini. Pada zaman rasul, Masjid memang berfungsi sebagai asrama untuk para pelajar suffah. Hal ini berarti sekitar 300 hingga 400 orang akan tinggal di Masjid untuk belajar. Ali menegaskan dikutip dari Republika Khazanah, jika kondisi ini diterapkan pada zaman sekarang dinilai kurang cocok. Menurut Ali, jika kondisi tersebut terjadi di zaman sekarang, Ali khawatir Masjid akan menjadi tempat yang kumuh. Kecuali, dia menambahkan, asrama itu dibangun di sekitar atau di luar bangunan Masjid. "Intinya, kelima fungsi atau aktivitas itu bisa dijalankan apabila dibangun di sekitar bangunaan Masjid. Jadi usahakan tidak menyatu dengan bangunan Masjid, "tambah Ali. 
Menurut Peneliti, apa yang disebutkan oleh Ali Musthafa Ya'kub tidaklah membatasi fungsi masjid di zaman Rasul pada saat itu. Karena ada beberapa fungsi masjid yang lain yang belum disebutkan. Hasil analisis peneliti dalam Al-Rahiq Al-Makhtum mendapatkan fungsi lainnya, yaitu sebagi tempat untuk menerima duta yang datang dari luar madinah, tempat untuk menawan tawanan, tempat berdiskusi dan berkumpul para sahabat, dan tempat untuk pertunjukkan beberapa hiburan.

Senada dengan fungsi masjid di atas, Quraish Syihab menuturkan, sebagaimana yang dinukil oleh Darodjat (2014:1-13) bahwa peranan masjid sangat banyak, diantaranya: sebagai tempat ibadah (shalat), tempat konsultasi dan komunikasi masalah-masalah ekonomi, social dan budaya, tempat pendidikan, tempat santunan sosial, tempat latihan militer, tempat pengobatan, aula dan tempat menerima tamu, tempat menawan tahanan, tempat perdamaian dan pengadilan sengketa, pusat penerangan dan pembelaan agama.

Dari pemaparan fungsi masjid sebagai pusat pendidikan di zaman Rasul, dapat kita fahami bahwa membangun masjid sebagai sarana pendidikan tidak dapat diabaikan dalam dunia pendidikan Islam.

\section{Membangun Persaudaraan Islam (ukhuwah Islamiyah)}

Menurut al-Mubarakfuri, setelah membangun masjid, manajemen pendidikan Islam berikutnya adalah membangun persaudaraan Islam (ukhuwah islamiyah). Hal itu telah Rasulullah kerjakan dengan cara mempersaudarakan antara kaum Muhajirin dan Anshar. Menurut peneliti, hal ini jika ditinjau dari berbagai aspek adalah sebuah langkah tepat dan bijaksana. Baik dari segi aspek pendidikan, ekonomi, kejiwaan para sahabat dan lain-lain.

Ibnul Qoyyim berkata sebagaimana yang dinukil oleh al-Mubarakfuri, "Kemudian Rasulullah mempersaudarakan antar Muhajirin dan Anshar dirumah Anas bin Malik. Mereka berjumlah 90 orang, separuh dari kalangan Muhajirin dan separuh lagi dari kalangan Anshar. Beliau mempersaudarakan diantara mereka untuk saling memiliki dan saling mewarisi setelah mati tanpa memberikannya kepada kerabat. Hal ini berlangsung hingga terjadinya perang Badar, namun setelah Allah menurunkan surat Al-Anfal ayat 75 yang artinya:

"Dan orang-orang yang beriman sesudah itu kemudian berhijrah serta berjihad bersamamu maka orang-orang itu termasuk golonganmu (juga). Orang-orang yang mempunyai hubungan kerabat itu sebagiannya lebih berhak terhadap sesamanya (daripada yang bukan kerabat) di dalam kitab Allah 些 Sesungguhnya Allah Maha Mengetahui segala sesuatu."

Hak saling mewarisi itu dihapus, sementara akad persaudaraan tetap berlaku (Al-Mubarakfuri, 2001:267). 
Maka, membangun persaudaraan diantara peserta didik sangatlah penting untuk memuluskan progam pendidikan. Hal itu karena tanpa rasa persaudaraan, maka yang ada hanyalah rasa permusuhan diantara mereka sehingga suasana dan kondisi tidak akan kondusif untuk pembelajaran dan pendidikan. Al-Mubarakfuri (2001:267) mengatakan: “ Persaudaraan ini mengandung pengertian meleburnya fanatisme jahiliyyah dan gugurnya segala perbedaan nasab, warna kulit dan tanah air, sehingga dasar alwala' dan albara' nya hanyalah Islam".

Menurut peneliti, berikut adalah penjelasan hikmah persaudaraan kaum Muhajirin dan Anshar dilihat dari beberapa aspek:

\section{a. Aspek pendidikan}

Dengan meleburnya segala fanatisme jahiliyyah (berbangga terhadap suku, kaum, warna kulit dan kedudukan) berganti dengan ukhuwah islamiyyah maka akan sangat berpengaruh terhadap proses pendidikan. Karena para peserta didik akan saling mengasihi, mendahulukan kepentingan saudara mereka, dan tidak ada rasa dengki dalam dada mereka, sehingga para peserta didik satu sama lain akan dapat saling mendukung dan bekerja sama.

\section{b. Aspek ekonomi}

Tidak dapat dipungkiri bahwa kaum Mahajirin ketika berhijrah ke Madinah mereka tidaklah memiliki harta benda seperti yang dimiliki kaum Anshar, berupa rumah, kebun, ternak dan lainnya. Mereka tidak memiliki tempat untuk berlindung, tidak memiliki pekerjaan untuk menafkahi kebutuhan mereka. Jumlah mereka tidaklah sedikit, setiap hari semakin bertambah (Al-Mubarakfuri, 2001:257). Hal ini tentu dapat menjadi permasalahan tersendiri dibidang ekonomi. Maka sungguh mempersaudarakan antara mereka adalah trik yang jitu dan bijak serta solusi yang cemerlang untuk mengatasi problematika tersebut.

Imam Al-Bukhari (1/553) meriwayatkan bahwa setiba di Madinah Rasulullah mempersaudarakan antara Abdurrahman bin Auf dengan Sa'ad bin Rabi, lantas Waktu itu Saad berkata kepada Abdurrahman:

"Saudaraku, aku adalah penduduk Madinah yang paling banyak hartanya, maka lihat dan ambillah separuh hartaku. Aku juga memiliki dua orang isteri, maka lihatlah yang paling menarik bagimu dari keduanya, nanti aku akan menceraikannya dan engkau bisa menikahinya."

Tetapi Abdurrahman bin Auf berkata, "Semoga Allah memberikan berkah dalam keluarga dan hartamu, maka sekarang tunjukkanlah aku jalan ke pasar." Mereka 
pun lantas menunjukkan kepadanya pasar Bani Qainuqo'. Abdurrahman pergi ke pasar, Ia melakukan aktivitas jual beli hingga memperoleh laba.

hal ini menunjukkan bahwa problematika ekonomi mampu diselesaikan oleh Nabi dengan cara salah ssatunya mempersaudarakan kaum Muhajirin dan Anshar. Sehingga yang kaya diantara mereka dapat membantu yang miskin. Atau kaum Muhajirin dapat bekerja dikebun-kebun kaum Anshar dengan sistem Muzara'ah (sistem bagi hasil).

\section{c. Aspek jiwa}

Ketika kaum Muhajirin berhijrah ke Madinah, tentu kondisi lingkungan, masyarakat dan kebiasaan Madinah sangat berbeda dengan kondisi tempat asal mereka yaitu Mekah. Rasa menjadi orang asing akan timbul dalam setiap jiwa yang berpindah tempat, karena tidak adanya sanak kerabat yang menemaninya. Oleh karena itu, dengan mempersaudarakan antara kaum Muhajirin dan Anshar adalah sangat bijak dan solusi tepat untuk menghilangkan perasaan keterasingan dalam jiwa kaum Muhajirin. Disamping itu, Rasulullah juga senantiasa mendorong rasa kasih sayang dan rasa persaudaraan diantara kaum Muslimin. Beliau bersabda:

"Seorang muslim itu saudara bagi muslim yang lainnya. Tidak boleh mendhaliminya dan tidak boleh pula menyerahkan kepada orang yang hendak menyakitinya. Barangsiapa yang memperhatikan kebutuhan saudaranya, maka Allah akan memperhatikan kebutuhannya. Barangsiapa yang melapangkan kesulitan seorang muslim, niscaya Allah 些 akan melapangkan kesulitankesulitannya di hari kiamat. Dan barangsiapa yang menutupi kesalahan seorang

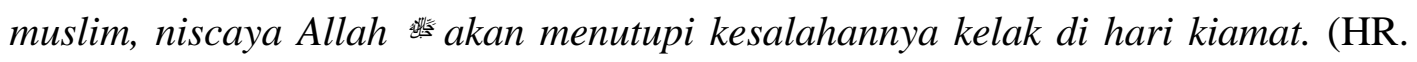
Al-Bukhori)

Hadits lain yang diriwayatkan oleh Imam Bukhari dan Muslim dari Anas bin Malik bahwa Rasulullah bersabda:

"Demi yang diriku di tangan-Nya, seseorang tidak dikatakan beriman, sebelum ia mencintai saudaranya, sebagaimana cintanya kepada diri sendiri". (HR. AlBukhori)

Dan masih banyak hadits-hadits lain yang memotivasi tentang persaudaraan dan kasih sayang diantara kaum muslimin. Yang demikian itu dapat menimbulkan rasa tentram dan aman bagi kaum Muhajirin, Seakan-akan mereka tidaklah berada di dalam negeri asing (Madinah) karena kebaikan dan kedermawanan para penduduknya. 


\section{Membangun Kerukunan Dengan Warga Sekitar}

Al-Mubarakfuri menyebutkan bahwa manajemen pendidikan Islam berikutnya setelah mempersaudarakan para peserta didik, adalah membangun kerukunan dengan warga sekitar lokasi pendidikan. Hal ini dibuktikan dengan apa yang telah dilakukan Rasulullah

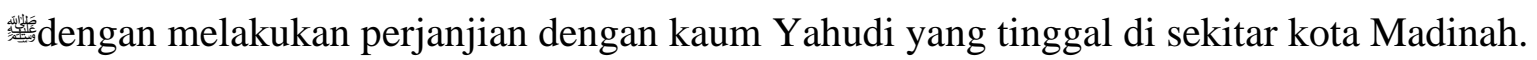
Perjanjian antara Nabi dengan kaum Yahudi penduduk Madinah ini di kenal dengan Piagam Madinah.

Setelah Rasulullah berhasil menancapkan pilar-pilar persaudaraan diantara kaum muslimin dengan membangun kesatuan akidah, politik dan peraturan diantara mereka, maka beliau mulai mengatur hubungannya dengan non Muslim. Tujuan beliau dibalik itu adalah memberikan rasa aman, damai, kebahagiaan dan kebaikan bagi seluruh umat manusia, disertai dengan pengaturan kawasan tersebut dengan satu kesepakatan (AlMubarakfuri, 2001:277). Karenanya Rasulullah membuat perjanjian dengan kaum Yahudi Madinah. Di dalamnya beliau memberikan keleluasaan bagi mereka untuk menyumbangkan nasihat dan berbuat kebaikan. Memberikan kepada mereka kebebasan dalam menjalankan urusan agama dan harta benda mereka (Al-Mubarakfuri, 2001:257).

Di antara isi Piagam Madinah sebagaimana yang disebutkan oleh al-Mubarakfuri adalah sebagai berikut:

a. Sesungguhnya orang-orang Yahudi Bani Auf Adalah satu kesatuan bersama kaum Mukminin; orang-orang Yahudi boleh menjalankan agama mereka dan kaum Muslimin juga menjalankan agama mereka. Ini berlaku untuk sekutu mereka dan mereka sendiri, demikian pula dengan orang-orang Yahudi selain Bani Auf.

b. Sesungguhnya kejadian dan pertengkaran yang timbul antara sesama penandatangan perjanjian ini yang dikhawatirkan berdampak negatif maka urusannya dikembalikan kepada Allah dan Muhammad Rasul-Nya.

c. Sesungguhnya di antara mereka terikat perjanjian saling membantu untuk melawan pihak musuh yang menyerang Madinah. (Al-Mubarakfuri, 2001:277-288).

Beberapa pelajaran yang dapat diambil dalam piagam Madinah menurut peneliti dilihat dari aspek pendidikan adalah sebagai berikut:

a. Pentingnya membangun kerukunan antara lembaga pendidikan dengan warga sekitarnya. Sikap toleransi tidak harus ikut melebur, sebagaimana Islam yang tidak melebur dengan ajaran dan kepercayaan agama-agama lain ketika Piagam Madinah disepakati. 
b. Pentingnya membangun komunikasi yang baik dengan warga sekitar lembaga pendidikan. Berkumpul dan bermusyawarah, adalah hal yang bagus untuk dilakukan untuk menyelesaikan persoalan-persolan bersama.

c. Mengakui dan menghormati eksistensi warga sekitar, karena lembaga tidak akan mampu menjalankan progam pendidikan mereka tanpa bantuan warga sekitar.

d. Pentingnya membuat kesepakatan hitam diatas putih (tertulis) antara lembaga dan warga sekitar. Hal ini untuk mengembalikan permasalahan yang dimungkinkan terjadi dimasa yang akan datang kepada kesepakatan yang telah dibuat.

e. Saling membantu antara lembaga dan warga sekitar untuk menciptakan suasana yang aman dan kondusif. Dengan cara mengadakan perjanjian keamanan dan membangun pos penjaga (security).

Piagam Madinah membuktikan bahwa lembaga pendidikan harus peduli dan memperhatikan warga sekitar. Kerukunan dan kerjasama antara lembaga dan warga harus senantiasa dibangun dan dijaga.

\section{Musyawarah}

Manajemen pendidikan Islam perspektif al-Mubarakfuri berikutnya adalah mengadakan musyawarah dalam menentukan suatu keputusan dalam pendidikan. Musyawarah dalam Kamus Besar Bahasa Indonesia (1989:603) adalah “ Pembahasan bersama dengan maksud mencapai keputusan atas penyelesaian masalah bersama. Selain itu dipakai juga kata musyawarah yang berarti berunding dan berembuk.

Pendapat Al-Mubarakfuri ini didukung oleh fakta sejarah Pendidikan Islam periode Madinah. Hal ini dibuktikan oleh perbuatan Rasulullah dengan para sahabat-sahabatnya dalam beberapa permasalahan yang belum terdapat petunjuk dari Allah dan dalam permasalahan duniawi. Quraisy Shihab (1996) mengatakan, "Karena persoalan-persoalan yang telah ada petunjukannya dari Tuhan secara tegas dan jelas, baik langsung maupun maupun melalui nabi-Nya tidak dapat dimusyawarahkan. Musyawarah hanya dilakukan pada hal-hal yang belum ditentukan petunjuknya, serta persoalan-persoalan kehidupan duniawi baik yang bersifat global maupun tanpa petunjuk yang mengalami perkembangan dan perubahan”.

Dalam Al-Rahiq Al-Makhtum periode Madinah, Peneliti menganalisis dan menemukan serangkaian peristiwa yang menunjukkan bahwa Rasulullah senantiasa bermusyawarah dengan para Sahabat untuk menentukan dan mengambil suatu keputusan. Di antaranya adalah sebagaimana berikut: 
a. Rasulullah bermusyawarah dengan para sahabat perihal para tawanan perang Badr. Abu Bakar bependapat, “ Wahai Rasulullah, mereka itu adalah anak-anak paman, keluarga besar dan saudara kita. Sesungguhnya aku berpendapat agar kita ambil tebusan saja dari mereka sehingga apa yang kita ambil itu menopang kekuatan buat kita untuk menghadapi kaum Kafir. Semoga saja dengan begitu, Allah 艦 memberikan hidayah kepada mereka sehingga mereka menjadi penolong kita."

Maka Rasulullah berkata, “ Bagaimana pendapatmu wahai Umar?” Umar berpendapat lain dengan mengatakan, “ Menurutku demi Allah 撉!, Aku tidak sependapat dengan Abu Bakar. Akan tetapi Aku berpendapat agar Engkau memberikan kepadaku si Fulan-seorang kerabat Umar biar aku penggal lehernya. Dan Engkau berikan juga perintah kepada Ali atas Aqil bin Abi Thalib agar dia memenggal lehernya, serta berikan pula perintah kepada Hamzah agar memenggal leher sanak saudaranya. Sehingga musuh-musuh Allah mengetahui bahwa di dalam hati kita tidak ada sikap lunak dan kasih terhadap kaum Musyrikin.”

Umar berkata," Maka Rasulullah lebih condong dengan pendapat Abu Bakar, tidak kepada pendapatku. Lalu beliau mengambil tebusan dari mereka." (AlMubarakfuri, 2001:336-337).

b. Rasulullah bermusyawarah dengan para sahabatnya perihal strategi yang tepat untuk menghadapi pasukan Musyrikin yang hendak menyerang kota Madinah sebelum perang Uhud. Rasulullah mengutarakan pendapatnya bahwa sebaiknya kaum muslimin bertahan dan tidak perlu keluar dari Kota Madinah. Sehingga ketika pasukan Musrikin datang dan menetap di perkemahan mereka, mereka akan menetap di tempat yang buruk dan tidak membuahkan hasil, namun jika mereka berani masuk, mereka akan diperangi kaum Muslimin di pintu-pintu gang dan dari atas atap-atap rumah.

Segolongan tokoh para sahabat mengusulkan kepada beliau agar keluar menyongsong pertempuran. Di antara mereka yang paling bersemangat adalah Hamzah bin Abdul Muththalib, ia berkata, “ Demi Dzat yang menurunkan AlQur'an kepadamu, aku tidak akan makan makanan hingga aku membabat leher mereka dengan pedangku di luar Madinah.”

Pada akhirnya Rasulullah membatalkan pendapatnya dan memutuskan untuk memilih pendapat para sahabat yang bersemangat untuk berperang ke luar Madinah di medan perang terbuka (Al-Mubarakfuri, 368-369). 
c. Rasulullah bermusyawarah dengan para sahabatnya untuk membahas strategi pertahanan yang tepat untuk menghadapi pasukan Ahzab. Setelah berunding cukup panjang antara para pemimpin dan pakar perang, mereka bersepakat dengan pendapat yang diusulkan oleh sahabat Salman Al-Farisi. Salman berkata, "Wahai Rasulullah, sesungguhnya dahulu ketika kami di negeri Persia, apabila kami dikepung musuh, maka kami membuat parit disekitar kami.” Maka Rasulullah bersegera melaksanakan rencana tersebut. Dan beliau mempercayakan kepada setiap sepuluh orang untuk menggali parit seluas empat puluh hasta. (AlMubarakfuri, 2001:444-445).

d. Rasulullah bermusyawarah dengan para sahabatnya perihal strategi beliau untuk memecah belah dan mengurangi jumlah pasukan Ahzab. Beliau mengutarakan pendapatnya untuk berdamai dengan pemimpin Bani Ghatafan, yaitu Uyainah bin Hishn dan Harits bin Auf. Yaitu dengan cara Beliau ingin menawarkan kepada pasukan Ghathafan sepertiga hasil perkebunan Madinah jika mereka mau kembali pulang dan tidak membantu pasukan Quraisy. Rasulullah meminta pendapat terlebih dahulu kepada Saad bin Muadz dan Sa'ad bin Ubadah sebagai pemimpin penduduk asli Madinah.

"Wahai Rasulullah jika Allah yang memerintahkan kami pasti tunduk dan patuh" demikian jawab keduanya, "namun jika ini pendapat Tuan kami tidak sependapat. Dulu orang Ghathafan tak pernah merasakan kurma Madinah, kecuali dengan membeli atau sedang diundang jamuan padahal waktu itu kami semua masih musyrik. Lalu mengapa kini setelah Allah memuliakan kami dengan Islam kami harus menyerahkan harta kami seperti itu? Demi Allah kami tidak akan memberikan sesuatu kepada mereka kecuali tebasan Pedang."

Rasulullah mengangguk setuju dengan pendapat kedua sahabat tersebut dan berkata, "Ini memang pendapatku sendiri sebab aku melihat orang-orang Arab menyerang kita dengan panah."

e. Rasulullah bermusyawarah dengan para sahabatnya ketika mengepung benteng Thaif. Setelah pengepungan berjalan cukup lama, dan musuh dapat bertahan didalam benteng mereka, maka Rasulullah meminta pendapat Naufal bin Mu'awiyyah Ad-Dili. Dia berkata, "Mereka adalah ibarat rubah di dalam lubang. Jika engkau tetap mengepung mereka engkau akan mendapatkannya, jika engkau meninggalkan mereka maka mereka pun tidak akan berbahaya." 
Beliau pun bermaksud hendak meninggalkan benteng dan pergi. Beliau memerintahkan Umar bin Al-Khattab mengumumkan kepada orang-orang, "Insya Allah 粞 besok kita akan pergi."

Tetapi ada di antara mereka yang keberatan dengan rencana ini. Mereka berkata, "Maka kita pergi begitu saja dan tidak menaklukkannya?"

"Kalau begitu serbulah mereka!" sabda beliau.

Tetapi justru serbuan yang mereka lakukan mengakibatkan banyak orang terluka, karena benteng musuh memang cukup kuat. Maka beliau bersabda, "Insya Allah 䦕 besok kita akan pergi."

Perintah ini justru membuat mereka merasa senang. Karena itu mereka pergi. Melihat hal ini beliau hanya bisa tersenyum. Setelah mereka beranjak pergi, beliau bersabda, "Ucapkanlah, 'Kami pasrah, bertaubat, menyembah dan kepada Rabb kami memuji". Ada yang berkata, "Wahai Rasulullah, berdoalah bagi kemalangan Tsaqif." Maka beliau bersabda,"Ya Allah 䅉, berikanlah petunjuk bagi penduduk Tsaqif dan limpahilah mereka (al-Mubarakfuri, 2001:624).

Dari uraian peristiwa musyawarah-musyawarah tersebut di atas, menunjukkan bahwa Nabi Muhammad adalah sosok pemimpin yang gemar bermusyawarah dengan para sahabat-sahabatnya. Bahkan didapatkan beberapa kali beliau menarik kembali pendapatnya dan lebih condong kepada pendapat para sahabat yang lain. Seperti dalam musyawarah penentuan strategi tempur sebelum berangkat ke perang Uhud sebagaimana yang telah diuraikan di atas.

Sikap Nabi Muhammad yang gemar bermusyawarah merupakan wujud implementasi atau pengamalan petunjuk Allah yang memerintahkan untuk senantiasa bermusyawarah. Allah berfirman dalam surat Ali Imran Ayat 159,

Maka disebabkan rahmat Allah-lah kamu berlaku lemah lembut terhadap mereka. Sekiranya kamu bersikap kasar lagi berhati keras tentulah mereka menjauhkan diri dari sekelilingmu. Karena itu maafkanlah mereka, mohonkanlah ampun bagi mereka dan bermusyawarahlah dengan mereka dalam berbagai urusan”.

Muhammad Abduh sebagai seorang tokoh pemikir pembaharauan dunia Islam menyatakan dalam kutipan Elwa (1983:21), bahwa berdasarkan ayat tersebut wajib hukumnya bagi setiap pemimpin muslim melaksanakan musyawarah dan membangun lembaga musyawarah yang bertujuan untuk mewujudkan persatuan dan kekuatan dikalangan umat. 


\section{Membangun dan Memperkuat Ekonomi Umat}

Hubungan antara pendidikan dan ekonomi sangatlah erat. Karena salah satu tujuan Pendidikan Islam adalah untuk membangun perekonomian umat. Dan untuk menjalankan program pendidikan juga harus ditopang oleh ekonomi yang kuat. Maka antara ekonomi dan pendidikan adalah dua hal yang tidak dapat dipisahkan. Hal ini senada dengan hasil penelitian pada Jurnal Pendidikan dan Kebudayaan bahwa hubungan kausalitas antara peranan pendidikan dan pertumbuhan ekonomi menjadi semakin terbukti dan kuat. Teori ini didukung juga oleh hasil penelitian Widiansyah (2017) yang menyatakan bahwa, "Dengan kebutuhan ekonomi yang semakin hari semakin meningkat, faktor pendidikanlah yang akan membantu pertumbuhan ekonomi itu, karena dengan pendidikan itulah akan menghasilkan kualitas-kualitas Sumber Daya Manusia (SDM) yang lebih profesional baik untuk sektor industri maupun sektor pertanian, dan dari situlah akan berdampak dan berpengaruh pada pertumbuhan ekonomi...” dan lebih lanjut Widiansyah (2017) juga mengatakan, "Pendidikan sangat memberikan kontribusi secara signifikan terhadap pembangunan ekonomi, hal ini telah menjadi sebuah justifikasi yang bersifat absolut dan aksiomatis. Berbagai kajian akademis dan empiris telah membuktikan keabsahan tesis tersebut." Oleh karena salah satu hal penting yang harus di perhatikan dalam dunia pendidikan adalah bagaimana membangun dan memperkuat ekonomi lembaga untuk kelancaran pendidikan.

Menurut Al-Mubarakfuri dalam Al-Rahiq Al-Makhtum, di periode Madinah Rasulullah juga membangun dan memperkuat perekonomian umat. Hal itu dapat dibuktikan dengan beberapa temuan hasil analisis Peneliti sebagaimana berikut:

a. Mempersaudarakan antara Muhajirin dan Anshar. Sehingga sahabat yang kaya dapat membantu sahabat yang miskin.

b. Menetapkan tebusan atas para tawanan perang. Seperti Rasulullah menerima tebusan dari para tawanan perang Badar.

c. Memotivasi kaum muslimin untuk giat bekerja dan melarang mereka untuk meminta-minta (mengemis).

d. Memotivasi kaum muslimin untuk bersedekah. Seperti para sahabat yang berlomba-lomba untuk bersedekah untuk membiyai kebutuhan operasional jihad dan lainnya.

e. Zakat, sehingga harta tidak hanya berputar di antara para orang kaya saja.

f. Menerapkan konsep Takaful (saling melindungi dan menolong) di antara penduduk Madinah. 


\section{KESIMPULAN}

Berdasarkan hasil penelitian ditemukan enam konsep manajemen pendidikan Islam periode Madinah perspekif Al-Mubarakfuri dalam kitab Al-Rahiq Al-Makhtum. Keenam konsep tersebut adalah, 1) menentukan lokasi sebagai pusat pendidikan, 2) membangun masjid, 3) membangun persaudaraan Islam (Ukhuwah Islamiyah), 4) membangun kerukunan dengan warga sekitar, 5) musyawarah, dan 6) membangun dan memperkuat ekonomi umat. Pertama, menentukan lokasi pendidikan dibuktikan dengan dipilihnya kota Madinah sebagai pusat pendidikan dan tindakan Rasulullah yang selalu memilih lokasi perkemahan pasukan yang strategis sebelum berperang. Kedua, membangun masjid pada masa Rasulullah tidak hanya dijadikan sebagai tempat sholat saja, tetapi juga dioptimalkan fungsinya sebagai asrama para Ahlu Shuffah, tempat menuntut ilmu, musyawarah, merawat orang sakit, untuk menerima duta yang datang dari luar madinah, tempat untuk menawan tawanan, tempat berdiskusi dan berkumpul para sahabat, tempat untuk pertunjukkan beberapa hiburan, tempat santunan sosial, dan tempat latihan militer. Ketiga, membangun persaudaraan Islam dilakukan oleh Rasulullah dengan mempersaudarakan antara sahabat Muhajirin dan Anshar untuk saling memiliki dan saling mewarisi setelah mati tanpa memberikannya kepada kerabat. Keempat, membangun kerukunan dengan warga sekitar dilakukan oleh Rasulullah dengan melakukan perjanjian dengan kaum Yahudi Madinah (Piagam Madinah). Di dalamnya beliau memberikan keleluasaan bagi mereka untuk menyumbangkan nasihat dan berbuat kebaikan. Memberikan kepada mereka kebebasan dalam menjalankan urusan agama dan harta benda mereka. Kelima, Musyawarah, hal ini sering dilakukan oleh Rasulullah di antaranya seperti musyawarah perihal tawanan perang Badar, strategi berperang sebelum berangkat ke Uhud, strategi bertahan menghadapi pasukan Ahzab, strategi memecah belah pasukan Ahzab, dan pengepungan benteng Thaif. Keenam, membangun dan memperkuat ekonomi umat, dilakukan Rasulullah dengan cara mempersaudarakan antara sahabat Muhajirin dan Anshar, menetapkan tebusan atas tawanan perang, memotivasi untuk giat bekerja, memotivasi untuk bersedekah, zakat, dan konsep takaful di antara penduduk Madinah.

\section{DAFTAR PUSTAKA}

\section{Sumber dari Jurnal}

Arumsari, Nurul Rizka. (2017). Penerapan Planning, Organizing, Actuating, Dan Controlling di Uptd Dikpora Kecamatan Jepara. Jurnal Ekonomi dan Bisnis Kontemporer, 3(2). 
Darodjat dan Wahyudiana. (2014). Menfungsikan Masjid Sebagai Pusat Pendidikan Untuk Membentuk Peradaban Islam. Jurnal ISLAMADINA, XIII(2): 1-13.

Jumari. (2014). Urgensi Manajemen Sarana Dan Prasarana Berkualitas Dalam Meningkatkan Kreativitas Peserta Didik. Jurnal Pendidikan dan Kebudayaan, 20(3).

Widiansyah, Apriyanti. (2017). Peran Ekonomi dalam Pendidikan dan Pendidikan dalam Pembangunan Ekonomi. Jurnal Cakrawala, XVII(2).

\section{Sumber dari Buku}

Abdul Rachman, Arifin. (2001). Administrasi Pemerintahan Dalam Pembangunan. Jakarta : CV. Haji Mas Agung.

Al-Bukhari, Abu Abdullah Muhammad bin Ismail. (2011). Ensiklopedia Hadits; Shahih AalBukhari 1. Jakarta: Almahira.

Al-Mubarakfuri, Shafiyyurrahman. (2001). Perjalanan Hidup Rasul Yang Agung Muhammad Jakarta: Mulia Sarana Press.

Al-Tirmidzi, Muhammad Bin Isa. (2008M/1429 H). Sunan At-Tirmidzi, bab Ma Jaa Fi Luzumil Jamaah, no 2167, Riyadh:Maktabah al-Ma'aarif Linnasyri Wattauzi'.

Arsyad, Azhar. (1996). Pokok-Pokok Manajemen. Yogyakarta: Pustaka Belajar.

Bungin, Burhan. (2006). Teknik-teknik Analisis Kualitatif dalam Penelitian Sosial dalam Burhan Bungin, ed, Analisis Data Pendekatan Kualitatif. Jakarta: PT RajaGrafindo Persada.

Bungin, Burhan. (2008). Penelitian Kualitatif. Jakarta: Kencana.

Choliq, Abdul. (2011). Pengantar Manajemen. Semarang: Rafi Sarana Perkasa.

Departemen Pendidikan dan Kebudayaan. (1989). Kamus Besar Bahasa Indonesia. Jakarta: Balai Pustaka.

Elwa, Muhammad S. (1983). On the Political System of Islamic State. Surabaya: Bina Ilmu.

Fattah, Nanang. (2004). Landasan Manajemen Pendidikan. Bandung: Remaja Rosdakarya.

Hafidudin, Didin dan Hendri Tanjung. (2003). Manajemen Syariah dalam Praktik. Jakarta: Gema Insani.

Handoko, Hani. (1999). Manajemen. Yogyakarta: BPFE Yogyakarta.

Handoko,T. Hani. (2003). Manajemen. Yogyakarta: BPPE Yogyakarta.

Hasibuan, Malayu S.P. (1996). Manajemen Dasar, Pengertian, dan Masalah. Bandung: PT Gunung Agung.

Kadarisman. (2013). Manajemen Pengembangan Sumber Daya Manusia. Jakarta: Rajawali.

Muhajir, Noeng. (1992). Metodologi Penelitian Kualitatif. Yogyakarta: Rake Sarasin.

Samsudin, Sadili. (2006). Manajemen Sumber Daya Manusia. Bandung: Pustaka Setia.

Shihab, Quraisy. (1996). Wawasan Al-Qur'an, Tafsir Tematik atas Pelbagai Persoalan Umat. Bandung: Mizan.

Sugiyono. (2006). Metode Penelitian Pendidikan Pendekatan Kuantitatif, Kualitatif dan $R \& D$. Bandung: Alfabeta.

Sule, Ernie Tisnawati et.al. (2010). Pengantar Manajemen. Jakarta: Kencana.

Tabrani, Abu Qosim Sulaiman bin Ahmad. (1415 H). Al-Mu'jam Al-Ausath. Kairo: Dar Al Haromaini.

Taufiqurokhman. (2008). Konsep dan Kajian Ilmu Perencanaan. Jakarta: Fakultas Ilmu Sosial dan Ilmu Politik Universitas Prof. Dr. Moestopo Beragama. 
Tim Dosen Administrasi Pendidikan Universitas Pendidikan Indonesia. (2011). Manajemen Pendidikan. Bandung: Alfabeta.

Yahya, Yohannes. (2006). Pengantar Manajemen.Yogyakarta: Graha Ilmu.

Zamani. (1998). Manajemen. Jakarta: IPWI.

https://kbbi.web.id/manajemen, dilihat pada 28 April 2020

https://megapolitan.kompas.com/kurang.dana.ruang.sekolah.yang.terbakar.tahun.lalu.belum.diperb aiki, dilihat pada Mei 2020.

https://metro.tempo.co/read/318772/pengusiran-sekolah-al-ishlah-diklaim-ada-dasar-hukumnya/ dilihat pada 24 April 2020

https://news.detik.com/konflik internal murid sd al azhar belajar di luar kelas, dilihat pada Mei 2020.

https://regional.kompas.com/cerita-di-balik-sekolah-kekurangan-murid-terancam-ditutup... di lihat pada 25 Mei 2020

https://www.ayobogor.com/read/2017/08/29/679/sengkarut-masjid-imam-ahmad-bin-hanbalberujung-pembekuan-izin. Dilihat pada 24 April 2020.

www. Repulika.co.id/khazanah, dilihat pada Ahad 17 Maret 2019, pukul 17.15 WIB. 